\title{
THE CILIARY FEEDING MECHANISM OF THE MEGATHYRIDAE (BRACHIOPODA), AND THE GROWTH STAGES OF THE LOPHOPHORE
}

\author{
By D. Atkins, D.Sc. \\ From the Plymouth Laboratory
}

(Text-figs. I-II)

The Megathyridae Allan 1940 is a family of brachiopods in which the adult lophophore is of simple design, bilobed (schizolophous) in Argyrotheca and four-lobed (ptycholophous) in Megathyris. Little is known of feeding mechanisms in the family. Hérouard (1877), finding it difficult or impossible to observe the feeding currents of living brachiopods, constructed artificial lophophores of lead piping with fine perforations corresponding to the position of attachment of the filaments. Through these he forced water, while the artificial lophophores were immersed in a bowl of water. He assumed, wrongly, that the result would be similar to the action produced by cilia vibrating in water. His remarks on the working of an artificial lophophore resembling that of Megathyris (=Argiope) were transcribed by Morgan (I883) without making it clear that the observations were not his own and were not made on the living animal. Apart from Hérouard's work on artificial lophophores, the only reference to feeding in a member of the Megathyridae is that of Shipley (1883) who merely mentioned that in Argyrotheca the arrangement of the cilia is adapted to bring particles into the ciliated groove and thence to the mouth. Thus an examination of the method of feeding of the Megathyridae was considered desirable, and was made possible in the first instance through the kindness of $M$. Paul Bourgis, then, in I955, on the staff of the Laboratoire Arago, Banyuls-surMer. He sent two small consignments of living Argyrotheca cordata (Risso), A. cuneata (Risso) and Megathyris detruncata (Gmelin), received on the 28 October and 24 December 1955. They were taken on 'fonds coralligènes (construits par des Lithothamnides)', the first being dredged off Cap d'Aseille at a depth of $30-40 \mathrm{~m}$, and the second from the Baie de Banyuls at a depth of 20-40 m. The successful method of sending these small brachiopods may be of interest. Each was rolled in damp filter-paper, and about a dozen packed in a little bag of thick polythene, which was then sealed and placed in a small $(4 \times 5$ in.) flat case of a special kind of papier mâché. The case was enclosed in a tough envelope and sent by air mail. All the brachiopods arrived in good condition, although those received in December had been out of water for five days.

Further Megathyris were dredged by R. V. 'Sarsia' in May I958 somewhat 
to the south-east of La Chapelle Bank ( $47^{\circ} 25^{\prime}$ N., $6^{\circ} 30^{\prime}$ W.) at a depth of ${ }^{320}-490$ fathoms, ${ }^{1}$ so that the exact depth is unknown, except that it was at least 320 fathoms. They were attached to the coral Lophelia prolifera (L.). These deep water Megathyris were of the transverse type. They did not attain the maximum size of those from Banyuls, the largest being $3.2 \mathrm{~mm}$ long and $4.6 \mathrm{~mm}$ wide, but they appear to be the same species, the only recent one of the genus. From these the growth stages have been worked out.

The Megathyridae withstand laboratory conditions well. Two Megathyris received from Banyuls in December 1955 lived until some time in 1958, when they disappeared after the entry of a crab from an adjoining tank. Specimens collected by R.V. 'Sarsia' in May I958 lived in the tanks to April I960, but there is evidently not sufficient food for them in the circulating water, for one opened in March 1960 was in a starved condition with very short filaments. Most of the few Argyrotheca were used within a few weeks of their arrival. One A. cordata, however, lived for over 6 months, but was in a starved condition when opened; the filaments were short and had dark orange coloured tips.

All figures, except Fig. 8, have been drawn with the aid of a camera lucida.

\section{THE ADULT LOPHOPHORE}

In Argyrotheca the invagination of the schizolophous lophophore (Figs. I, 2) is occupied by a triangular septum, with its apex just in front of the mouth. In the young the septum has the shape of an isosceles triangle; in the adult it rises gradually from the anterior margin of the valve to its apex, then drops steeply to the valve floor, with a slight concavity facing posteriorly. At a length and width of $3.6 \mathrm{~mm}$-the largest seen-the septum of $A$. cordata was not connected by a ridge with the cardinalia, but was followed posteriorly by a slight groove, with a low rounded ridge on each side. It is apparently in larger specimens than those seen that it is continued as a ridge to the cardinalia, as described and figured by Davidson (I887). The crest of the septum is toothed in $A$. cordata, smooth in $A$. cuneata.

The lophophore is supported by descending branches of the loop, which in A. cordata was said by Davidson ( 1887, p. 132) to be 'two-lobed, attached to the base of the hinge-plate and again to the anterior extremity of the submarginal septum, and more or less confluent with the valve'. His largest specimen was $2 \frac{1}{2}$ lines long and 2 lines wide, that is about 5.3 by $4.2 \mathrm{~mm}$. Schulgin (1885) figured, under the name Argiope kowalevskii, incomplete descending branches in an individual of which the size was not given. Shipley (I883) figured and described them as incomplete at a shell length and width of $3 \mathrm{~mm}$. He stated 'although these plates do not form a continuous support in front, there are traces of them in the anterior border, in the form of small ${ }^{1}$ Given previously (Atkins, 1959 a) as $400-405$ fathoms and since corrected. 


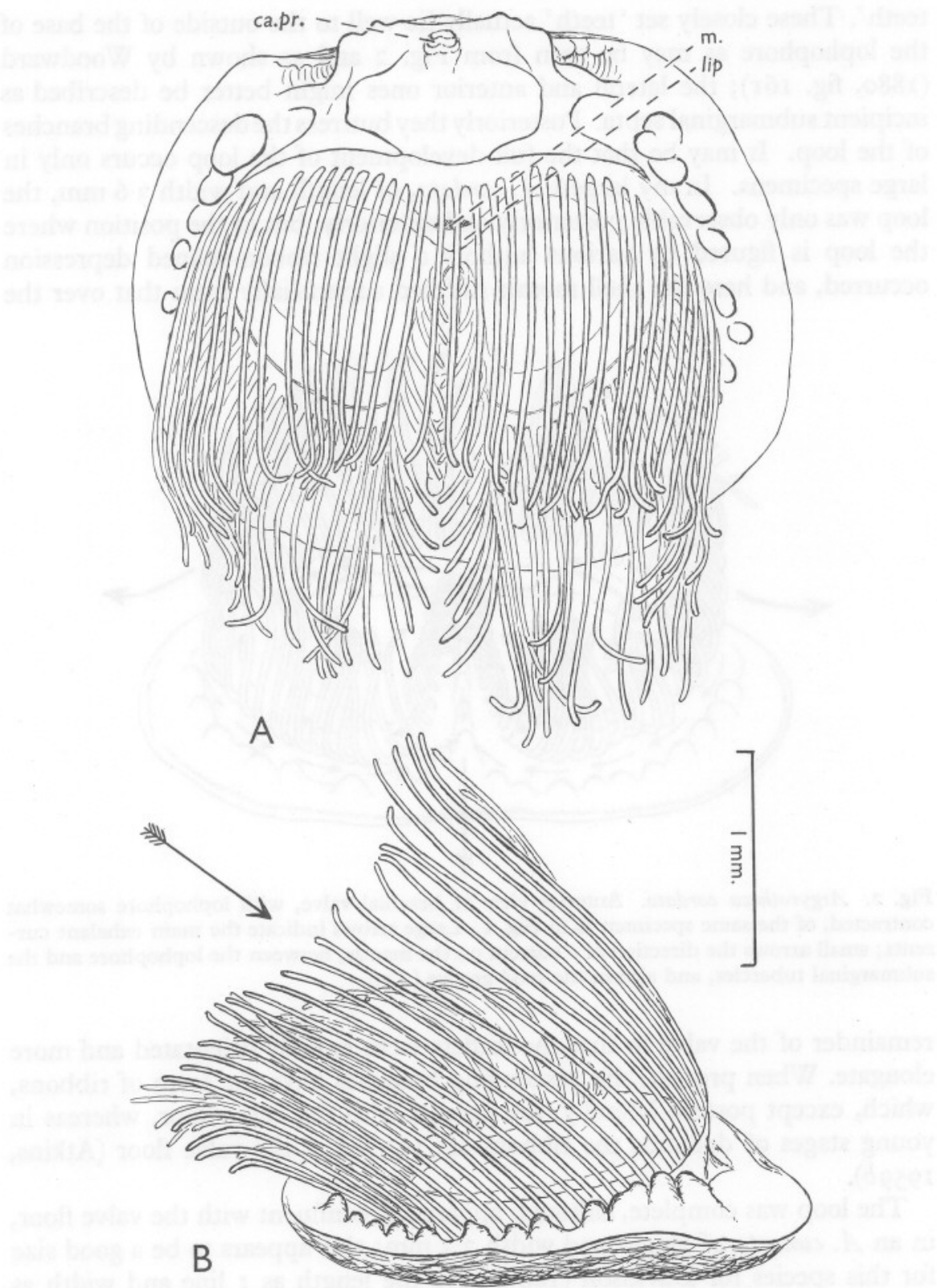

Fig. I. Argyrotheca cordata of shell-length $3.0 \mathrm{~mm}$ and width $2.9 \mathrm{~mm}$. Brachial valve with adult schizolophous lophophore, drawn living after narcotizing. A, ventral; and B, lateral view. ca.pr., cardinal process; lip, lip of the food groove; $m$., mouth. The arrow shows the direction of the inhalant current. 
teeth'. These closely set 'teeth' actually lie well to the outside of the base of the lophophore as may be seen from Fig. 2 and as shown by Woodward (1880, fig. I6I); the lateral and anterior ones might better be described as incipient submarginal septa. Posteriorly they buttress the descending branches of the loop. It may be that the full development of the loop occurs only in large specimens. In my largest $A$. cordata, of length and width $3.6 \mathrm{~mm}$, the loop was only observable posteriorly and anteriorly, but in the position where the loop is figured by various authors a slight ribbon-shaped depression occurred, and here the shell mosaic differed superficially from that over the

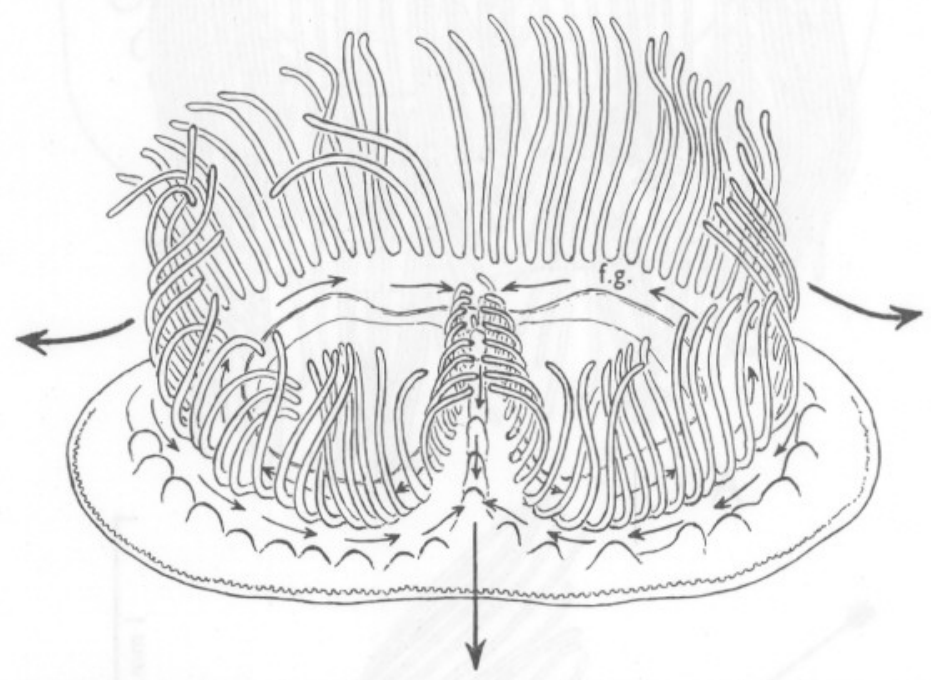

Fig. 2. Argyrotheca cordata. Anterior view of brachial valve, with lophophore somewhat contracted, of the same specimen as in Fig. I. Large arrows indicate the main exhalant currents; small arrows the direction of a current on the mantle, between the lophophore and the submarginal tubercles, and also in the food groove (f.g.).

remainder of the valve in that the leaflets were radially orientated and more elongate. When present, the descending branches have the form of ribbons, which, except postero-laterally, are parallel with the valve floor, whereas in young stages of dallinids the ribbons are vertical to the valve floor (Atkins,

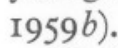

The loop was complete, although apparently confluent with the valve floor, in an A. cuneata of length and width $3.3 \mathrm{~mm}$ : this appears to be a good size for this species for Davidson (I887) gave the length as I line and width as 2 lines. Schulgin's (1885) measurements cannot be relied on as he confused the various dimensions of the brachiopod shell. It is to be noted that Blochmann (1910) described an incomplete loop in A. australis of length and width $3 \mathrm{~mm}$. 
Postero-laterally the descending branches of the loop support the lophophore as it passes from body to mantle. The filaments lining the sides of the median invagination are carried just below the anterior face of the septum, and as this runs at an angle to the valve floor, so does the line of filaments; the latest formed filaments arise near the apex of the septum, almost on a level with the mouth. By this arrangement the lophophore slopes both from the crest of the septum to the lateral mantle margins and from a high position posteriorly to the anterior mantle margin as shown by Shipley (1883, figs. 2, 3) and Schulgin (I885, figs. I5-I8).

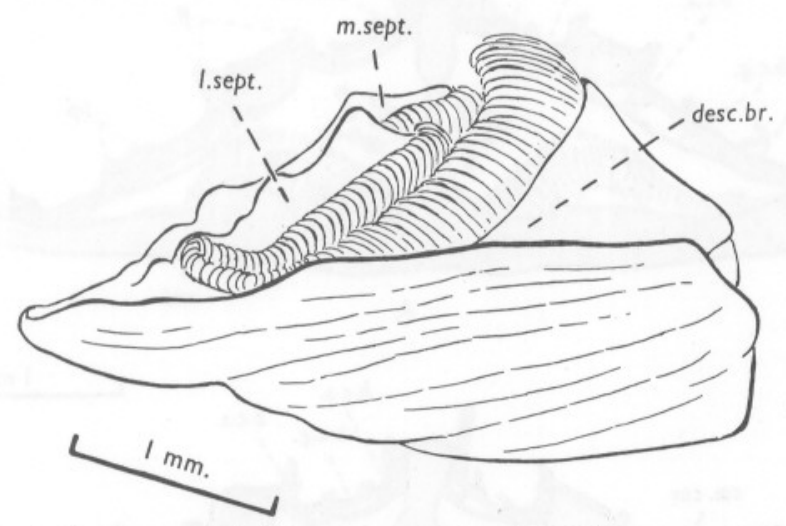

Fig. 3. Megathyris detruncata of shell length $4.8 \mathrm{~mm}$ and width $5.5 \mathrm{~mm}$. Side view of brachial valve with ptycholophous lophophore strongly contracted, to show the postero-anterior slope of the lophophore. desc.br., descending branch of the loop; l.sept., lateral septum (right); m. sept., median septum.

In Megathyris detruncata the adult lophophore is ptycholophous, there being a lateral invagination occupied by a septum on each side of the median septum. The lateral septa usually are not as high or as long as the median one, which has its apex just in front of the mouth. Occasionally five septa are present (Fischer \& Oehlert, I89I, p. I04), but the additional two may be small and rudimentary, no doubt resembling the small submarginal septa of Argyrotheca cordata. The septa have sloping anterior faces, whilst posteriorly they drop steeply to the valve floor, with a slight backward-facing concavity; this was shown by Morgan (I883, figs. 6, 7). The crests of the septa are toothed. Morgan (1918) suggested that the schizolophe of Argyrotheca is derived from the ptycholophe of Megathyris by atrophy of the lateral septa. Thomson (1927, pp. 2II-I2) discussed this and concluded that the reverse was true, Megathyris passing through a schizolophous stage in its development. At the time he was writing the growth stages of the lophophore of Megathyris were unknown; the present work on them supports his conclusions. In the Megathyris examined, the descending branches of the loop could be clearly traced in some adults. 
The filaments forming the sides of the invaginations arise just below the crests of the septa, and the brachial membrane, or floor of the lophophore, slopes to the frontal and lateral margins of the valves (figs. 3, 4).

On each side of the lophophore a small brachial canal, arising from a perioesophageal space, runs at the bases of the filaments and gives off a branch to each. In Megathyris a large brachial canal underlies the brachial membrane (Fig. 4, b.c.g.): this canal is most probably present in Argyrotheca, but in the
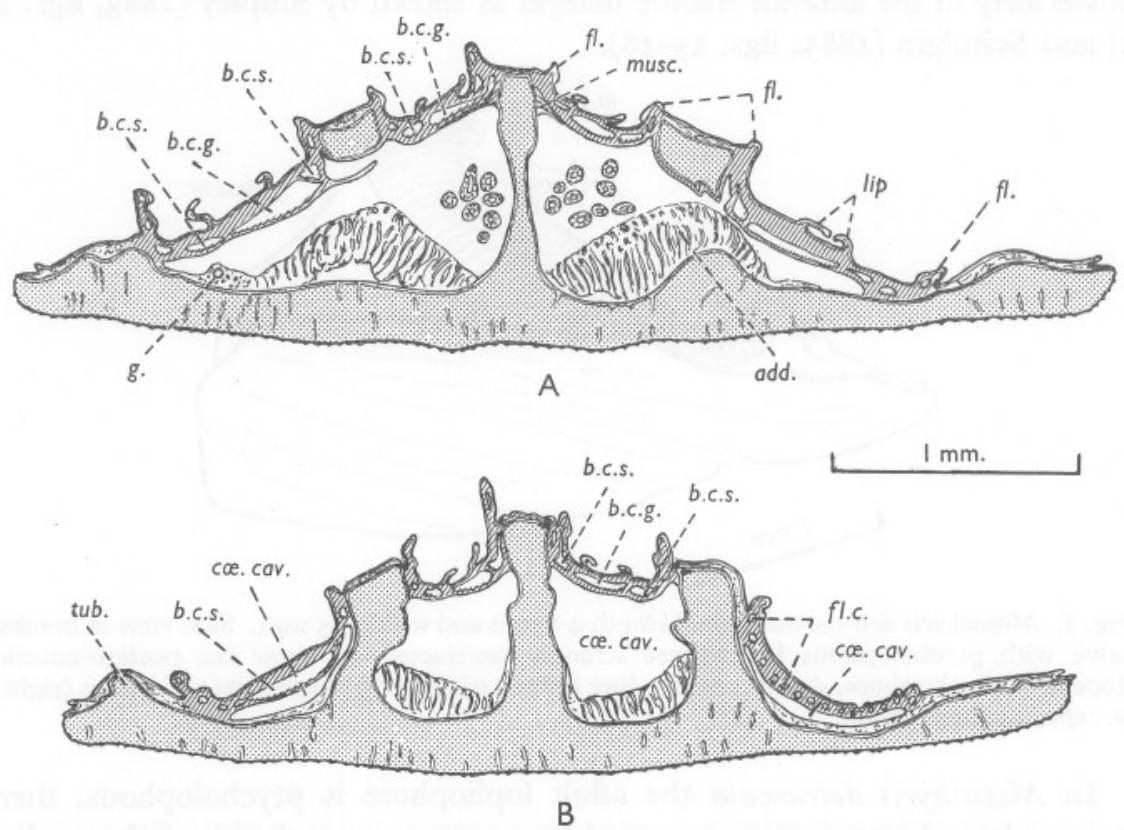

Fig. 4. Megathyris detruncata. Transverse sections of a specimen of shell length $3 \cdot 8 \mathrm{~mm}$ and width $5.2 \mathrm{~mm}$. A, through the posterior region of the lophophore, the backwardly projecting crests only of the lateral septa being cut; B, through the anterior region of the lophophore, near to the anterior ends of the lateral lobes. add., adductor muscles; b.c.g., great and b.c.s., small brachial canals; coe.cav., coelomic cavity; $f$., filament and filament base; fl.c., filamentar canals; g., gonad; lip of the food groove; musc., muscle fibres; tub., tubercle.

small specimen sectioned, of length $2 \cdot 6 \mathrm{~mm}$ and width $2 \cdot 2 \mathrm{~mm}$, it was most difficult to trace owing to collapse of its wall. In Argyrotheca the coelomic cavity, divided into two by mesentery and septum, underlies the lophophore to its anterior edge. In Megathyris the cavity is divided anteriorly into four by the three septa and these branches extend to the anterior extremities of the lobes of the lophophore (Fig. 4). Muscle fibres attached near the crests of the septa run under the great brachial canals.

The section illustrated in Fig. 4B passes on the left anterior to the great brachial canal and on the right anterior to both small and great canals. 
Shipley (1883, p. 507) described nerves passing to the lophophore; unfortunately the fixation of the specimens I sectioned was not good and the position and distribution of the nerves could not be determined.

In both Argyrotheca and Megathyris the filaments are all in a single series, an arrangement I have so far found only in these genera, but it probably occurs in Lacazella (= Thecidea) mediterranea (Risso), judging from the figure in Davidson's paper of I852. It was noted by Dall (I871, p. 22) in Argyrotheca lutea (Dall) and both Shipley (I883) and Schulgin (I885) figured a single row in Argyrotheca: Thomson (1927) seems to have overlooked this fact. All the filaments have rounded or ridged frontal surfaces, resembling

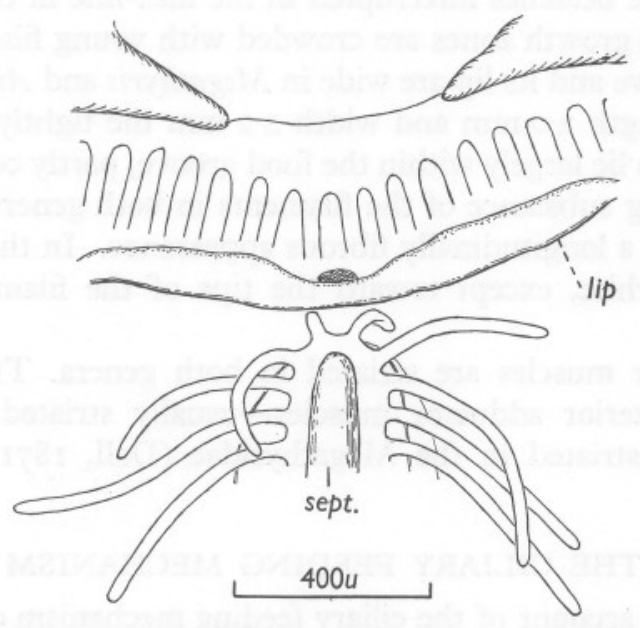

Fig. 5. Argyrotheca cordata of shell length and width $2.7 \mathrm{~mm}$. To show the uninterrupted base of the lophophore and the uncrowded growth zone with two filament buds only. The filaments on the side of the septum are turned outward, as when the lophophore is partly contracted. This figure also shows the proximity of the mouth to the excurrent channel formed when the filaments bordering the septum are turned toward each other in the feeding animal. The lip of the food groove is turned outward. lip, edge of lip; sept., septum.

the inner filaments of other brachiopods (Atkins, I958, fig. I3A). This arrangement and type of filament is possibly primitive, for in the brachiopods examined, including the inarticulate Crania, a certain number of the first formed filaments, which come to lie behind the mouth in the adult, are in a single series and are of the inner series type, although all other filaments are in a double alternating series of two types. The inarticulates Lingula and Glottidia differ in having all filaments in a double series.

Thomson (I927, p. 204) considered that the Megathyrinae Dall I870 (= Megathyridae Allan 1940) were not ancestral to the Dallininae or Magellaniinae Beecher I893 (= Terebratellinae Davidson I886), but that Megathyris represents the highest development of a stock which branched off 
at an early stage of terebratellid development and was one of the two main divisions of the original terebratellid stock. The arrangement of the filaments in a single series supports Thomson's view.

In the Megathyridae the posterior and lateral filaments are long (Figs. I B and 7); they gradually decrease in length anteriorly and bordering the septa, the shortest occurring at the posterior edge of the median septum where new filaments arise. The base of the lophophore is continuous in the adult, as in the trocholophous stage, and filament buds are usually no more than two, of unequal length (Fig. 5). This is in contrast with the condition in those articulates with plectolophes or with spirolophes in the adult and in which the base of the lophophore becomes interrupted in the mid-line in the schizolophous stage and the two growth zones are crowded with young filaments and buds.

The food groove and its lip are wide in Megathyris and Argyrotheca. In an A. cordata of length $2.0 \mathrm{~mm}$ and width $2 \cdot 2 \mathrm{~mm}$ the tightly coiled filaments were once seen to lie largely within the food groove, partly covered by the lip.

The supporting substance of the filaments in both genera is thick, especially basally, with a longitudinally fibrous appearance. In the living animal it shows shining white, except toward the tips of the filaments where it is attenuated.

The filamentar muscles are striated in both genera. This is of interest because the posterior adductor muscles-usually striated in articulatesappear to be unstriated in the Megathyridae (Dall, I87I; Shipley, I883; Atkins, 1958)

\section{THE CILIARY FEEDING MECHANISM}

The following account of the ciliary feeding mechanism of the Megathyridae is based on an investigation of Argyrotheca cordata, A. cuneata, and Megathyris detruncata: the water currents were observed chiefly on Megathyris and proved exceptionally interesting because of the surprising reversal of the water currents, not so far seen in a brachiopod outside this family.

The Megathyridae were amongst the most difficult brachiopods studied; not only were they particularly sensitive to the slightest vibration, which caused them to close and remain closed for varying, but long periods, but after separation of the valves the filaments relaxed only slightly after $24 \mathrm{~h}$, and attempts to relax them with $\mathrm{I} \%$ stovaine and with $7 \frac{1}{2} \%$ magnesium chloride proved only partially successful: the latter was the more effective of the two.

Argyrotheca and Megathyris are attached by a short pedicle in a position almost at right angles to the substratum, and their beaks therefore suffer attrition. The valves gape to an angle of $40-45^{\circ}$, but this was only seen to occur after the animals had been in the laboratory tanks for some weeks. One Argyrotheca cordata extended the filaments well beyond the shell edge, as in Schulgin's (1885) figure 5. Observations on feeding were mostly made on Megathyris 
and most successfully on animals which had been in the tanks for 4 months, and when the temperature of the water was rising in April.

The position of the filaments during feeding was observed in a large Megathyris, about $6 \mathrm{~mm}$ long and $8 \mathrm{~mm}$ wide, which had been stood almost upright and was gaping widely so that the posterior ends of the three septa and the mouth could be seen. The filaments behind the mouth were erect except distally where they curved forward and touched on the anterior edge of the pedicle valve, extending beyond it slightly. The lateral filaments stood nearly erect, but slanting slightly forward, as did those at the anterior ends of the lobes-and curved slightly outward at their tips. The filaments on each side of a septum generally curved toward each other at their tips, but otherwise were nearly erect. Flocculent matter from the peridinian culture was seen to travel up the posterior filaments to their tips, where it remained. The tiny square-sided lappets edging the mantle lobes project at right angles to the valves. They probably interdigitate when the valves are closed, or nearly closed.

\section{The ciliation of the lophophore}

The single series of filaments have ciliated cells in three tracts, frontal and paired lateral.

The frontal cilia are long, about $20 \mu$, and, as in other brachiopods examined (Atkins, 1956, 1958, I959 $a, b, c$ ), are capable of reversal, beating either toward the base or toward the tip according to the quantity and size of particles impinging on the frontal surfaces of the filaments. In Phoronis also similar reversal of the frontal currents has been observed (Atkins, unpublished).

The lateral cilia, about $30 \mu$ long, beat across the length of the filaments and have a well-marked dexioplectic metachronal wave. The lateral cilia, as well as the frontal, are able to reverse their beat (seen in Megathyris).

Abfrontal cilia could not be distinguished living and no abfrontal current could be detected: the abfrontal surface of the filament is small.

Shipley (1883, pl. 39, fig. I3) figured the cilia on the lateral and frontal surfaces of the filaments as all of the same length, while Schulgin (I885, pl. 9, fig. 26) showed the frontal cilia longer than the lateral, whereas the reverse occurs.

The brachial membrane is ciliated as shown by the movement of particles adhering to the tips of cilia: such currents as were observed passed toward and over the lip and into the food groove present at the bases of the filaments. The groove is interrupted near the posterior edge of the median septum, that is at the growth zone, and particles entering the groove on each side of it pass in opposite directions to the mouth. It is evident that on one side of a lobe the current in the groove is anterioriy directed and on the opposite side posteriorly directed (Fig. 8). The mouth, a large transverse slit, opens, as is usual, within the food groove in the mid-line posteriorly. 


\section{The ciliation of the mantle}

In both species of Argyrotheca the mantle is ciliated: this is evident from the occasional movement of particles adhering to cilia, but although the animals were in good condition clear currents could rarely be demonstrated. On the posterior region of the pedicle valve a general anterior movement of particles was observed, as also along the crest of the median septum. The lophophore occupies much of the brachial valve: over the posterior region of the valve currents passed anteriorly and laterally. In $A$. cordata at the bases of the filaments, a broad current, between them and the submarginal tubercles, passed anteriorly and medianly and swept upward on to the median septum, joining the anteriorly directed current along its ventral edge (Fig. 2). This latter current is on the floor of the excurrent channel. No currents could be demonstrated between the submarginal tubercles and the mantle edge, although it seems probable that such exist. Submarginal tubercles are absent in A.cuneata.

In Megathyris, as in Argyrotheca, mantle currents were most difficult to demonstrate, although the movement of particles adhering to the tips of cilia, is evidence that the mantle is ciliated. In one specimen, on the third day after separation of the valves, feeble currents on the pedicle valve passed anteriorly to the free edge of the mantle. As in Argyrotheca the great extent of brachial valve occupied by the lophophore leaves only a small area of mantle exposed, and currents were not observed, except for an anteriorly directed current along the crest of the median septum.

\section{The water currents (Figs. I, 2, 5-8)}

In Megathyris with valves gaping naturally, unnarcotized, the broad inhalant current is median and as it closely approaches the lophophore is drawn into the four lobes (two in Argyrotheca); the main part of the current, however, appears to pass into the posterior region of the lophophore where the posterior and lateral filaments are particularly long and so play a major part in creating the current. The filaments bordering the three septa generally curve toward each other over the septa-this is especially apparent over the median septum - their tips approaching or interdigitating, thus forming three excurrent channels. The exhalant current escapes between the filaments, and is strongest at the postero-lateral angles of the shell where it is fed by currents passing between the long posterior filaments and which can only escape here. Three antero-dorsal exhalant currents pass from the three excurrent channels floored by the septa and bordered by filaments. In both genera the median dorsal excurrent channel has its origin in front of the mouth where the filaments are short (Fig. 5). It is possible that this channel may carry away material voided from the mouth, although this has not been seen to occur. On one occasion in Argyrotheca the lip in front of the mouth was 


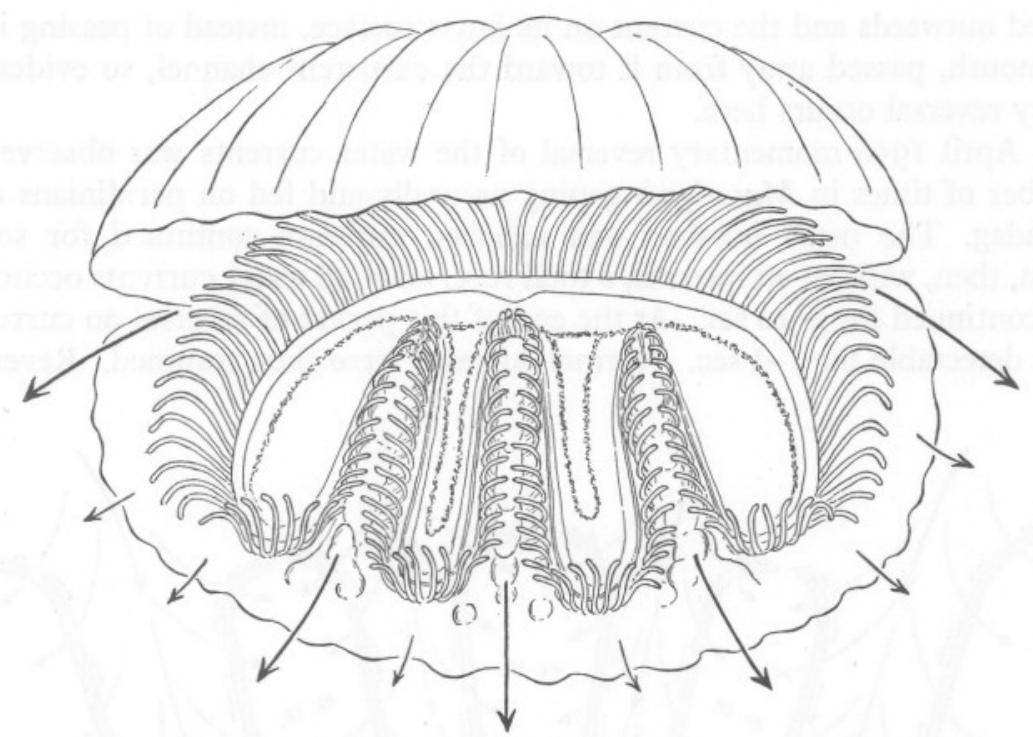

Fig. 6. Megathyris detruncata, View through the anterior gape of a feeding animal (unnarcotized), somewhat diagrammatic; filaments foreshortened. The exhalant currents only can be shown, for the inhalant currents enter the lophophore from the direction of the observer. Tracts of mucous glands on the brachial membrane are indicated.

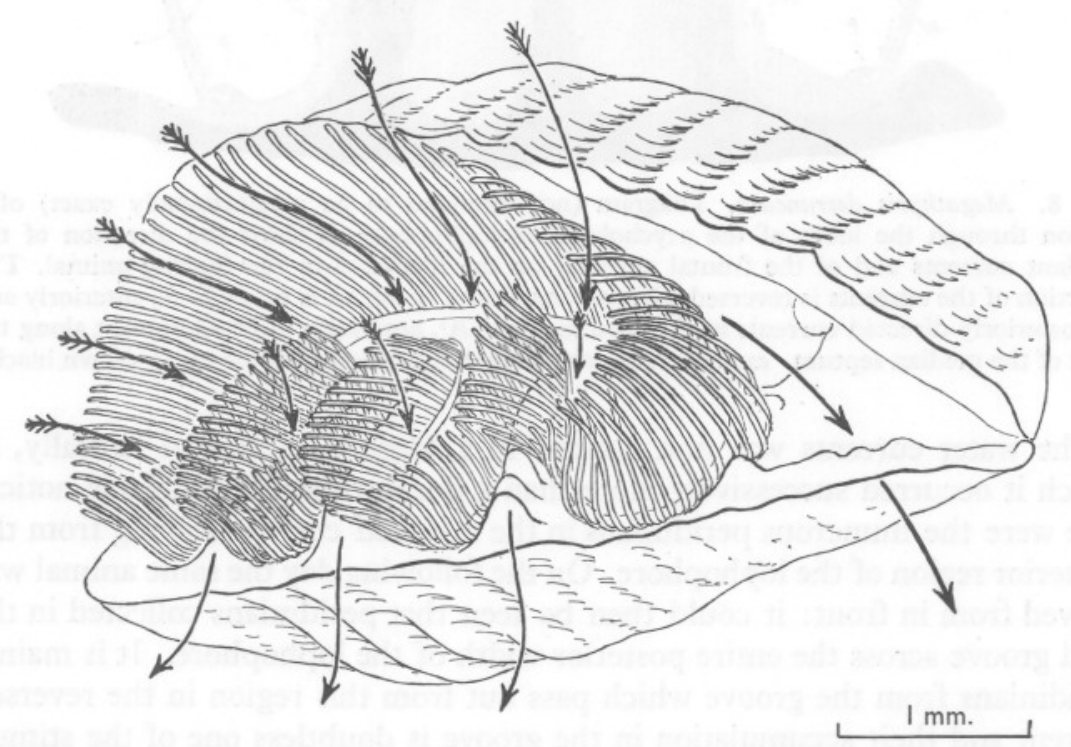

Fig. 7. Megathyris detruncata. Obliquely lateral view of a feeding animal to show the usual inhalant (feathered arrows) and exhalant (plain arrows) currents. Currents are reversed when strong cleansing action is needed. 
turned outwards and the current on its inner surface, instead of passing into the mouth, passed away from it toward the excurrent channel, so evidently ciliary reversal occurs here.

In April 1956 momentary reversal of the water currents was observed a number of times in Megathyris gaping naturally and fed on peridinians and Aquadag. The usual inhalant and exhalant currents continued for some $5 \mathrm{~min}$, then, without an interval, a total reversal of all water currents occurred and continued for $3-\mathrm{IO}$ sec. At the end of this period of reversal no currents were detectable for I-2 sec. Normal currents were then resumed. Reversal

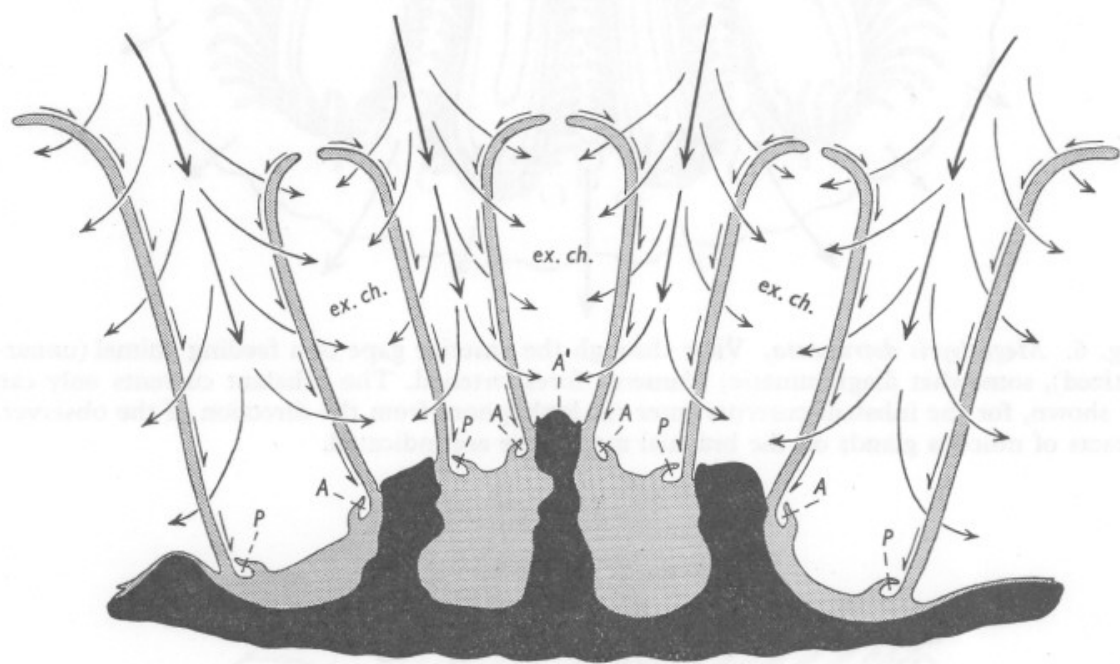

Fig. 8. Megathyris detruncata. Diagram (not intended to be proportionally exact) of a section through the lobes of the ptycholophous lophophore to show the direction of the inhalant currents and of the frontal currents on the filaments in the feeding animal. The direction of the currents is reversed when strong cleansing action is needed. A, anteriorly and $\mathrm{P}$, posteriorly directed currents in the food grooves. $\mathrm{A}^{1}$, anteriorly directed current along the crest of the median septum. ex.ch., excurrent channel. The shell with the septa shown black.

of the water currents was first noticed in a Megathyris viewed laterally, in which it occurred successively more than a dozen times. Particularly noticeable were the numerous peridinians in the reversed current leaving from the posterior region of the lophophore. On the following day the same animal was viewed from in front: it could then be seen that peridinians collected in the food groove across the entire posterior width of the lophophore. It is mainly peridinians from the groove which pass out from this region in the reversed current and their accumulation in the groove is doubtless one of the stimuli which sets off the reversal. The peridinians passing out were separate and not bound together by mucus.

The reversed water current is almost certainly due to reversal of the beat of 
the lateral cilia, although this could not be seen owing to the opacity of the valves and the low magnification which had to be used, nor could the metachronal wave be seen which might have given some indication of change of direction of beat. The valves were gaping widely, as in Figs. 6 and 7, and no movement of them or of the lips of the food groove could be detected, in fact no muscular movement whatever could be detected which might account for the reversal. On the third day the same animal, still in front view with valves gaping widely, but now with the filaments curved inwards and no water current detectable, suddenly showed slight reversed current.

Another Megathyris with valves gaping, but with filaments curved inwards at about half their length, showed no water currents or frontal currents on the filaments. A little Aquadag in sea water was dropped on to the lophophore and fell mostly into the two inner lobes. With the filaments still curved inwards, the reversed current began, and this apparently before any material had reached the mouth region. In this instance also a careful watch revealed no muscular movements.

On all occasions the reversed current was a steady continuous stream for the short while it lasted, and, judging from the movement of particles, quite as strong as the usual current. It would not appear possible that the frontal cilia beating toward the tips of the filaments could produce so strong a current, although Megathyris is a small animal: moreover, reversal of the water current seems to be set off by the collection of particles in the food grooves, whereas reversal of the frontal currents is caused by material impinging on the frontal surfaces of the filaments. Evidently the direction of the water current is reversed when strong cleansing action is called for.

Many Aquadag particles and peridinians passed out between the filaments all around the lophophore, yet a surprising number of the latter accumulated in the food groove across the posterior region of the lophophore.

Slight transverse movement occurred of particles on to the crests of the lateral septa, whence they were removed by the water current. The median septum had an anteriorly directed current along its crest, but the lateral septa appeared to be without such a current.

\section{The frontal currents on the filaments}

The frontal cilia of the filaments as mentioned previously (p. 467) are able to reverse their beat. Small particles impinging on the frontal surfaces are carried basally into the food grooves and thence to the mouth. The reversed currents toward the tips of the filaments are rejection currents and are seen when large or too many small particles are supplied. From the tips of the filaments rejected material drops off into the exhalant current. The rejection currents on the frontal surfaces of the filaments can occur without reversal of the inhalant and exhalant currents. 


\section{THE BEHAVIOUR OF ARGYROTHECA CORDATA DURING THE ESCAPE OF LARVAE}

It is known from the work of Senn (1934) that Argyrotheca cordata and A.cuneata are hermaphrodite. They have paired brood pouches in which the ova develop and from which the free-swimming larvae escape (Kovalevsky, 1874, I883; Shipley, 1883; Schulgin, I885; Plenk, 1913). Larvae of both species were seen during October to January while the adults lived in the tanks.

Two $A$. cordata were watched under a dissecting microscope whilst liberating larvae. They opened widely, kept the filaments tightly folded inwards and at intervals snapped the valves together. The larger specimen (shell length $2.9 \mathrm{~mm}$ and width $3.0 \mathrm{~mm}$ ) was watched for $\frac{1}{2} \mathrm{~h}$, during which time eight larvae escaped at varying intervals. The anterior commissure of the shell was facing upwards and the posteriorly situated brood pouches were visible through the gape. Part of the left lobe of the lophophore was wanting: the filaments of the right lobe were kept folded inwards, the posterior filaments were at times extended. Five of the larvae left the parent rapidly, swimming from the brood pouches and keeping near the pedicle valve; they swam toward the light and the surface of the water. Of these, four came from the left and one from the right pouch. When the valves first gaped a larva was seen caught in the filaments of the right side; it failed to escape during the $\frac{1}{2} \mathrm{~h}$ the animal was watched. The first two larvae from the left pouch swam out in quick succession; the third after a long interval and the fourth near the end of the period of watching. They all left the shell ventrally and laterally. A fifth left this brood pouch, but failed to escape before the valves closed indefinitely. The first larvae to leave the right brood pouch swam out and away rapidly. The second nosed about, finally passed to the left side, escaping near the hinge and dropping to the bottom of the dish. The third behaved in the same manner, but was three times caught by the edges of the valve closing on it, the anterior lobe being outside. Finally, snapping of the valves shot it outside. On examination it appeared that this treatment had done it little harm. A fourth on leaving the brood pouch nosed about and was eventually shot out of the shell by closing of the valves. Judging by their behaviour these larvae were either unhealthy or had escaped prematurely. It is probable that larvae normally leave the parent rapidly, and during their escape the filaments are kept folded inwards so as not to interfere with their movements.

Larvae escaping naturally from these and other $A$. cordata in November I955 lived some Io days, but failed to attach themselves to the glass of the dish. Shipley $(1883$, pl. 40, figs. 28,29$)$ showed clearly the appearance of the ring of long and powerful swimming cilia when at rest and distinguished between them and the shorter, less active, cilia clothing the anterior lobe. $\mathrm{He}$ made certain observations on the behaviour of the free-swimming larvae. 


\section{THE IMMATURE SHELL OF MEGATHYRIS DETRUNCATA}

Certain immature shells of Megathyris detruncata are figured (Figs. 9B, C, D and I0) to show the change in shape with age from elongate to transverse. The three smallest found were from Banyuls, attached near to or on adults. It cannot be altogether certain that these minute brachiopods, the largest $0.69 \mathrm{~mm}$ long, are Megathyris, for Argyrotheca cordata and A. cuneata were received at the same time, and all three megathyrids were probably dredged together. At this size it is doubtful if the three species could be distinguished with certainty. However, it is clear from the growth lines on the shell of the smallest Megathyris, length and width $0.97 \mathrm{~mm}$, dredged by R.V. 'Sarsia' that when younger the shell was longer than wide. At a length of about I mm, width becomes greater than length and it is near this size that the first two rounded plicae are evident, with, between them a gentle indentation of the anterior shell edge (Fig. IOA, B); this becomes deeper with age (Fig. IOF). Terebratalia transversa (Sowerby), markedly transverse in the adult, is also elongate in the early stages (Atkins, I959c), but this change in shape is of particular interest in the Megathyridae because of discussions by Jeffreys (I880), Davidson (I887), Fischer \& Oehlert (I89I) and Dall (I92I) as to whether Gwynia capsula (Jeffreys) is an adult or an immature form of another species of megathyrid, such as Argyrotheca cistellula (Searles Wood) with which it is found. Thomson's (I927, p. 208) statement that it 'cannot be the young of that species from its more elongate form' is thus questionable. Jeffreys (I880), Davidson (I887) and Fischer \& Oehlert (I89I) were unable to find septum or loop in Gwynia capsula about $\mathrm{I} \cdot 75 \mathrm{~mm}$ long and $\mathrm{I} \cdot 3 \mathrm{~mm}$ wide. This is perhaps not altogether surprising as Jeffreys for one soaked the minute shells for several days in 'dilute potash water'. Such treatment is apt to cause disintegration of the shell in adult brachiopods before the flesh is sufficiently dissolved to brush or blow out of the shell. This is no doubt because organic matter enters into the shell substance. Dall (I92I, p. 325), in the larger specimens he examined, found a distinct loop with its lower edge cemented to the valve, and thought the species sufficiently distinct though very near to Argyrotheca cistellula.

As Megathyris passes through a schizolophous stage at a shell length of I-2 mm, where it is found together with Argyrotheca it may in some instances be somewhat difficult to distinguish between the two genera at that size, although Megathyris is likely to have greater width.

\section{THE GROWTH STAGES OF THE LOPHOPHORE AND LOOP}

Two minute brachiopods, 0.34 and $0.72 \mathrm{~mm}$ long were found attached to an adult Argyrotheca cordata and were possibly or probably the young of that species. In both the lophophore was completely circular. The smaller had 


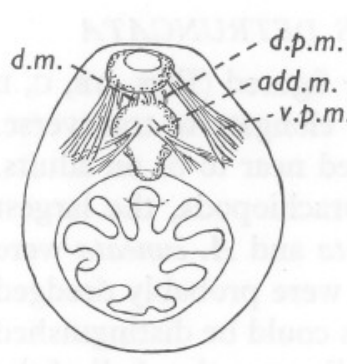

A

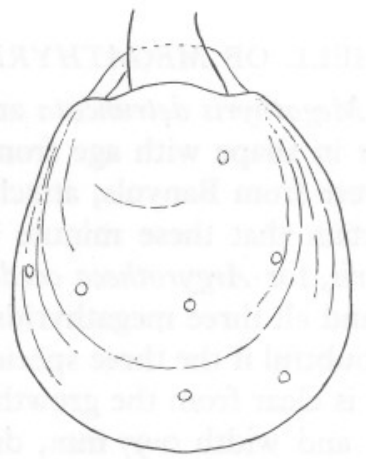

B

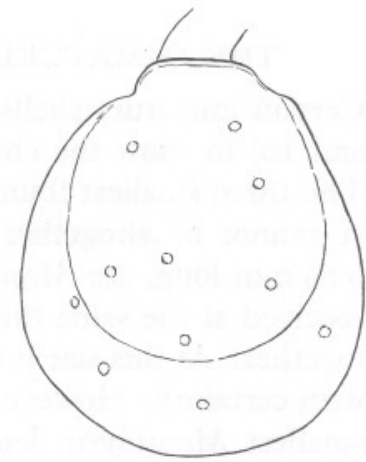

C

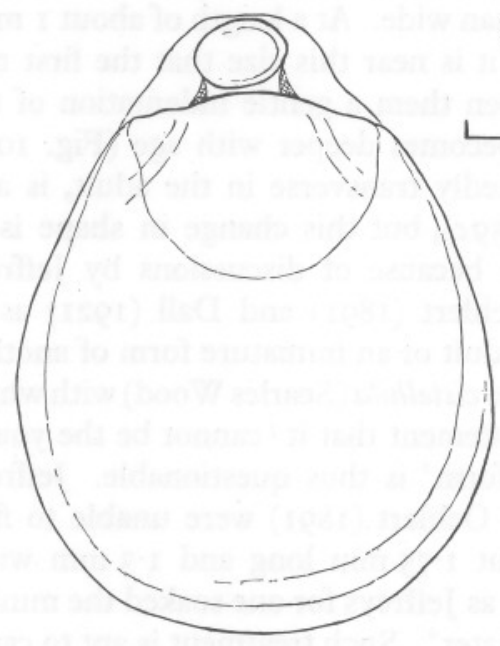

D

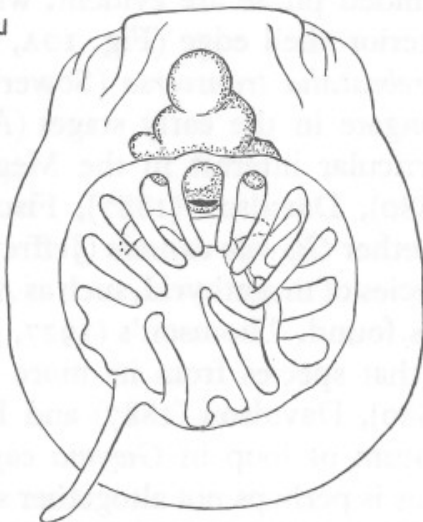

E

Fig. 9. A, Argyrotheca cordata: ventral view of a specimen of shell length $0.34 \mathrm{~mm}$ and width $0.29 \mathrm{~mm}$, which was attached to an adult of that species; pedicle retracted. B-E, Megathyris detruncata from Banyuls-sur-Mer, two of which (B-D) were attached near to, and one (E) on an adult of that species. B, dorsal and C, ventral view of specimen of shell length $0.44 \mathrm{~mm}$ and width $0.38 \mathrm{~mm}$; D, dorsal view of specimen of shell length $0.69 \mathrm{~mm}$ and width $0.52 \mathrm{~mm}$; , brachial valve with trocholophe of a specimen of shell length 0.62 and $0.46 \mathrm{~mm}$. add.m., adductor muscle; d.m., diductor muscle; d.p.m., dorsal and v.p.m., ventral pedicle muscles.

four pairs of filaments and a bud; a small pre-oral lobe was present (Fig. 9A). Intestine and digestive diverticulata were as yet undifferentiated. This is a somewhat younger stage than that illustrated by Kovalevsky (1874) and reproduced by Oehlert \& Deniker (I883) as their figure II, for it has fewer filaments. Kovalevsky showed Io filaments, but probably at least I2 were present, those behind the mouth being omitted, no doubt because they were obscured by the oesophagus and digestive diverticula. (In this figure 
the adductor muscles were apparently labelled diductors by Kovalevsky, although they are correctly identified in a figure of an older stage-Oehlert \& Deniker I883, fig. I3.) The larger specimen had nine pairs of filaments and a bud; the lobe in front of the mouth had extended laterally to about the base of the second or third filament on each side. Intestine and digestive diverticula were differentiated. This is about the same stage as that shown in Kovalevsky's figure reproduced by Oehlert \& Deniker (I883) as their figure I3. In this figure only I4 filaments are shown, those behind the mouthprobably numbering four-again being omitted. I found no intermediate stages between these tiny individuals and the adult.

The growth stages of the lophophore of Megathyris detruncata have been worked out chiefly from material dredged by R.V. 'Sarsia', the youngest, however, were from Banyuls, attached near or on adults. The two attached near an adult Megathyris were $0.44 \mathrm{~mm}$ long and $0.38 \mathrm{~mm}$ wide (Fig. 9B, C) and $0.62 \mathrm{~mm}$ long and $0.46 \mathrm{~mm}$ wide. Although the smaller remained attached to the substratum, the tissue had deteriorated and the lophophore could not be distinguished: a few mantle pits were present. The lophophore of the larger was trocholophous, of the broad based terebratellacean type set low on the dorsal mantle, with eight pairs of filaments, the last on the right being a bud: two filaments on the left were abnormal (Fig. 9E). The lip of the food groove extended only a short distance on each side of the mouth. A third specimen $0.69 \mathrm{~mm}$ long and $0.52 \mathrm{~mm}$ wide (Fig. 9D) was attached to an adult Megathyris. It had a trocholophous lophophore with nine pairs of filaments: the lip of the food groove extended less than half way around the lophophore.

In the contracted condition the tips of the filaments were pointed inwards. When narcotized and expanded they extended upwards, outwards and forwards. Particles passed down the filaments and toward the mouth following the position of the food groove, although it was as yet unprovided with a complete lip. Reversal of the frontal cilia was not obtained on these tiny brachiopods because of the difficulty of dealing with them. The usual inhalant current would set into the circle of filaments and out between them, as described for the trocholophous stage of the lophophore in Terebratulina retusa by Atkins (1956).

The young Megathyris now to be described were dredged by R.V. 'Sarsia'. That shown in Fig. IOA-E had a length and width of $0.97 \mathrm{~mm}$ with the frontal edge of the shell slightly indented. The lophophore was damaged anteriorly, it was probably still trocholophous. Descending branches had grown from the crura (Fig. IOD). The dorsal septum was represented by a slight ridge in the mid-line. In the ventral valve a septum was present: the pedicle collar was fairly deep and had longitudinal pits (Fig. IOE).

A transverse individual of shell length $\mathrm{I} \cdot 0$ and $\mathrm{I} \cdot 2 \mathrm{~mm}$ had a well-developed median septum and the lophophore, with about I4 pairs of filaments, slightly invaginated in the mid-anterior line. Descending branches from the crura 
had increased in length; their anterior ends could not be distinguished on the septum, but might have been hidden by filaments.

In a slightly larger, but less transverse individual, I. $2 \mathrm{~mm}$ long and $\mathrm{I} \cdot 3 \mathrm{~mm}$ wide, the anterior invagination of the lophophore had deepened and

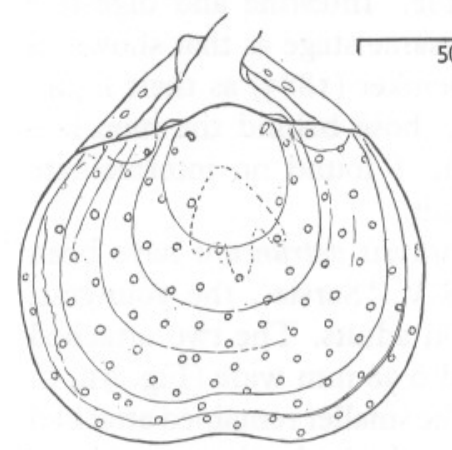

A

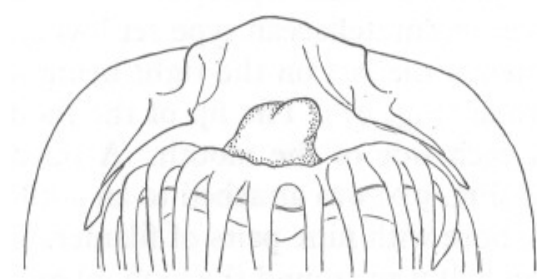

$\mathrm{D}$

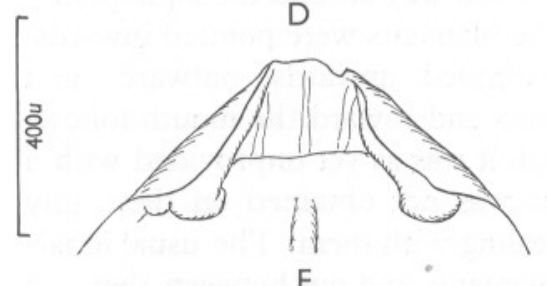

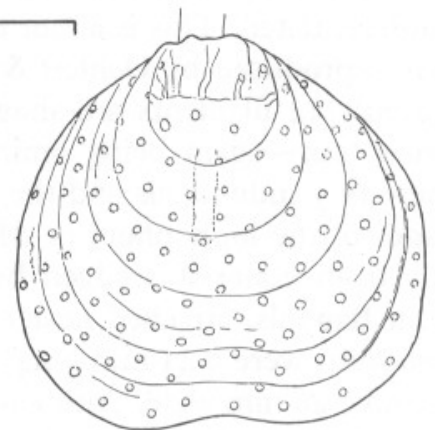

B

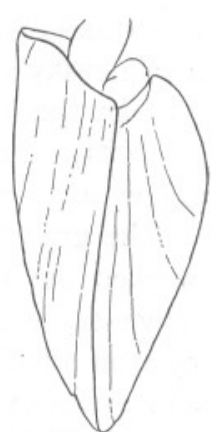

C

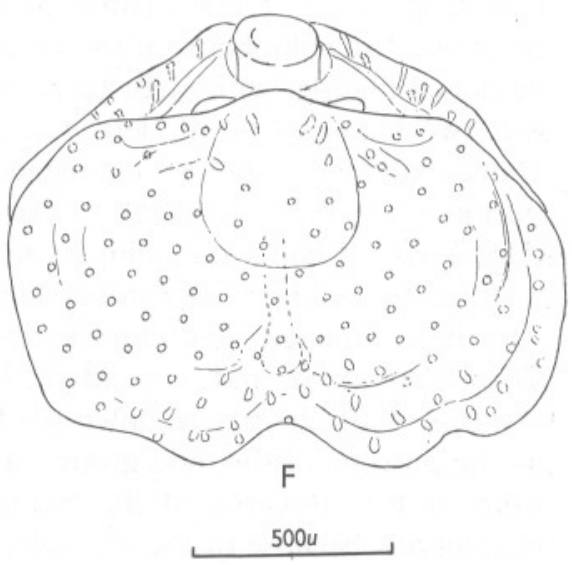

Fig. 10. Megathyris detruncata from near La Chapelle Bank, one (A-E) of shell length and width $0.97 \mathrm{~mm}$ and the other $(\mathrm{F})$ of shell length $\mathrm{I} \cdot \mathrm{I} \mathrm{mm}$ and width $\mathrm{I} \cdot 4 \mathrm{~mm}$. A, dorsal; B, ventral (ventral septum indicated by a broken line); c, lateral views; D, posterior region of the brachial valve to show the cardinalia and descending branches of the loop; $\mathrm{E}$, umbonal region of pedicle valve to show the pedicle collar and the teeth; F, dorsal view with dorsal septum indicated by broken line.

descending branches had grown from near the ventral surface of the median septum (Fig. II). The filaments in this individual were somewhat shorter than normal: it was possibly not entirely healthy, as it, and the previous specimen, had lived in the laboratory tanks for I 6 months. These three individuals of length $0.97, \mathrm{I} \cdot 0$ and $\mathrm{I} \cdot 2 \mathrm{~mm}$ all had a gentle indentation of the anterior edge of the shell, due to the development of the first two plicae. Another two, 
of shell length $\mathrm{I} \cdot \mathrm{I}$ and $\mathrm{I} \cdot 4 \mathrm{~mm}$ with early schizolophes, had in addition lateral indentations (Fig. IOF). The test of these small specimens was fairly thick.

At a shell length of $\mathrm{I} .8 \mathrm{~mm}$ and width of $2.65 \mathrm{~mm}$ the lophophore was late schizolophous. No lateral septa were as yet present, and marginal tuberculation was absent. At length of $2 \cdot 2 \mathrm{~mm}$ and width of $3.2 \mathrm{~mm}$ the lophophore was still in the same stage. Lateral septa were tiny and the lophophore only slightly indented, or rather flattened where these occurred. The margin had

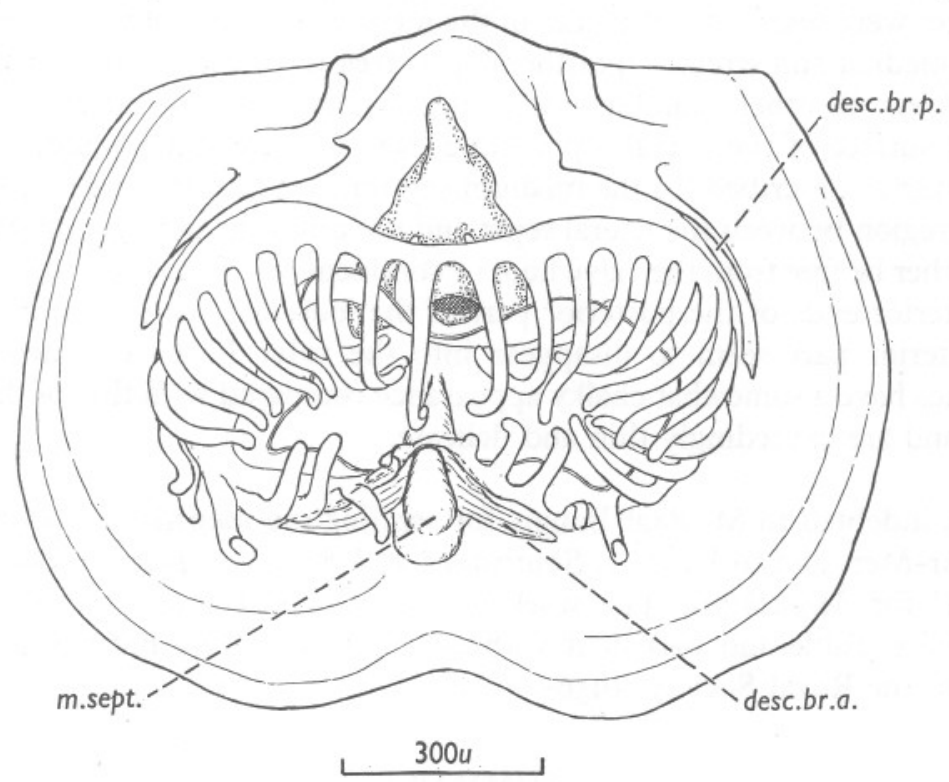

Fig. II. Megathyris detruncata of shell length $\mathrm{I} \cdot 2 \mathrm{~mm}$ and width $\mathrm{I} \cdot 3 \mathrm{~mm}$. Brachial valve with early schizolophe. The anterior ends of the descending branches (desc.br.a.) have grown from the median septum (m.sept.,) which alone is present. desc.br.p., posterior end of descending branch of the loop. The filaments are shorter than normal. Drawn living, but not successfully relaxed.

slight tuberculations postero-laterally. At a length of $2.4 \mathrm{~mm}$ and width of $2.7 \mathrm{~mm}$ the lateral septa were larger and the lophophore was ptycholophous.

Thomson's (1927, p. 214) description of the loop of Megathyris was as follows 'loop consisting of two descending branches which are free only near the crura, but descend (dorsally) to join the floor of the valve, rising over the two lateral septa, descending again to the floor of the valve, and attached to the sides of the median septum'. In Argyrotheca he described the descending branches as joining the anterior end of the median septum: according to him (p. 2I2) the loop-development of Megathyris had not then been clearly established. A loop which may disappear or be adherent to the valve floor in parts is puzzling, but I think it can be stated that in Megathyris the descending branches of the loop grow both from the crura and the median septum, 
and the junction of the two parts occurs in the region between the lateral septa and the crura. The anterior ends of the branches appear to arise at the crest of the median septum, in fact to overlie it, and run down its sides, with the anterior edges projecting as flanges all around the anterior face of the septum. This was seen at a shell length of $3.5 \mathrm{~mm}$ and width of $4.7 \mathrm{~mm}$. Megathyris did not give good sections, owing to the large proportion of shelly matter, however, in the two individuals sectioned, it appeared that the descending branches were fused with the sides of the medium septum. Between the bases of the median and lateral septa the loop is free from the valve floor in some Megathyris, in others confluent with it. The loop appears to run over the ventral surface of the lateral septa while these are still tiny, its anterior edge projecting as described for the medium septum, yet may be fused with them. In the region between the lateral septa and the crura the descending branches may either be free from the valve floor or confluent with it, in the latter instance the anterior ends of the posterior part of the loop and the posterior ends of the anterior part seem to disappear into the valve floor. The descending branches have a somewhat chalky appearance compared with that of the valve floor, and are exceedingly thin and delicate.

I am indebted to M. Paul Bougis for sending me megathyrids from Banyuls-sur-Mer, and to Dr A. J. Southward and the Captain and crew of R.V. 'Sarsia' for Megathyris. The work was done whilst occupying a London University Table and part of it with assistance from the Browne Research Fund of the Royal Society, 1956-57.

\section{SUMMARY}

The structure of the adult lophophores of Argyrotheca and Megathyris is described. In megathyrids the filaments are in a single series and all of the same type. The ciliary feeding mechanism differs from that previously described by the writer in brachiopods in that in addition to reversal of the frontal cilia, reversal of the inhalant and exhalant currents occurs.

The behaviour of Argyrotheca cordata during the escape of larvae from the brood pouches is briefly described.

Certain of the growth stages of the shell and of the lophophore and loop of Megathyris are described and figured. Megathyris passes through a schizolophous stage resembling the adult lophophore of Argyrotheca.

\section{REFERENCES}

ALLAN, R. S., I940. A revision of the classification of the terebratelloid Brachiopoda. Rec. Canterbury [N.Z.] Mus., Vol. 4, pp. 267-75.

Atrins, D., I956. Ciliary feeding mechanisms of brachiopods. Nature, Lond., Vol. I77, pp. 706-7. 
Atkins, D., 1958. A new species and genus of Kraussinidae (Brachiopoda) with a note on feeding. Proc. zool. Soc. Lond., Vol. 131, pp. 559-81.

- I959 $a$. The growth stages of the lophophore of the brachiopods Platidia davidsoni (Eudes Deslongchamps) and P. anomioides (Philippi), with notes on the feeding mechanism. F. mar. biol. Ass. U.K., Vol. 38. pp. I03-32.

- I $959 \mathrm{~b}$. The early growth stages and adult structure of the lophophore of Macandrevia cranium (Müller) (Brachiopoda, Dallinidae). F. mar. biol. Ass. U.K., Vol. 38, pp. 335-50.

- I959c. The growth stages of the lophophore and loop of the brachiopod Terebratalia transversa (Sowerby). F. Morph., Vol. I05, pp. 40I-26

Blochmann, F., I9Io. In Verco, J. C. The Brachiopods of South Australia. Trans. roy. Soc. S. Aust., Vol. 34, pp. 89-99.

DALL, W. H., I87I. Report on the Brachiopoda obtained by the United States coast survey expedition, in charge of L. F. de Pourtalès, with a revision of the Craniidae and Discinidae. Bull. Mus. Comp. Zool. Harvard, Vol. 3, pp. I-45.

- I92I. Annotated list of the recent Brachiopoda in the collection of the United States National Museum, with descriptions of thirty-three new forms. Proc. U.S. nat. Mus., Vol. 57, pp. 26I-377.

DAvidson, T., 1852. Sketch of a classification of Recent Brachiopoda; based upon internal organization. Ann. Mag. nat. Hist., Ser. 2, Vol. 9, pp. 36I-77.

— 1887. A Monograph of Recent Brachiopoda. Part II. Trans. Linn. Soc. Lond. (Zool.), Ser. 2, Vol. 4, pp. 75-182.

Fischer, P. \& OeHLeRT, D.-P., I891. Brachiopodes. Expéd. sci. Travailleur et Talisman, I $40 \mathrm{pp}$.

HÉROUARD, J., I877. Sur les courants de nuitrition des brachiopodes. F. conchyliol., Sér. 3, T. 17.

Jefrreys, J. G., I880. Note on Argiope capsula. Ann. Mag. nat. Hist., Ser. 5, Vol. 6, pp. 406-7.

Kovalevsky, A. O., I874. [On the development of the Brachiopoda. Title in Russian.] Izvyest. imp. Obsch. Lyubit. Estestv. Anthrop. i. Ethnog. Moscow, Vol. I4, pp. I-40 (in Russian-not seen). Analyse par Oehlert et Deniker, 1883, Arch. Zool. exp. gén., Ser. 2, T. I, pp. 57-76.

Morgan, J. DE, I883. Note sur quelques espèces nouvelles de Mégathyridés. Bull. soc. zool. France, T. 8, pp. 371-96.

- I918. Considérations générales sur les Mégathyridés, leur origine et leur croissance. Bull. Mus. Hist. nat., Paris, T. 24, pp. 187-95.

Plenk, H., I913. Die Entwicklung von Cistella (Argiope) neapolitana. Arb. zool. Inst. Univ. Wien., Bd. 20, pp. 93-108.

Schulgin, M. A. 1885. Argiope kowalevskii. (Ein Beitrage zur Kenntnis der Brachiopoden). Z. wiss. Zool., Bd. 4I, pp. II6-4I.

SENN, E., I934. Die Geschlechtsverhältnisse der Brachiopoden, im besonderen die Spermato- und Oogenese der Gattung Lingula. Acta zool., Stockh., Bd. I5, pp. I-I52.

ShIPLeY, A. E., I883. On the structure and development of Argiope. Mitt. zool. Sta. Neapel, Bd. 4, pp. 494-520.

Thomson, J. A., 1927. Brachiopod morphology and genera (Recent and Tertiary). Manual N.Z. Bd. Sci. Art, No. 7.

Woodward, S. P., 1880. A Manual of the Mollusca. 4th edition. London: Crosby Lockwood. 